\title{
Growth Respiration, Maintenance Respiration, and Carbon Fixation of Vinca: A Time Series Analysis
}

\author{
Marc W. van Iersel ${ }^{1}$ \\ Department of Horticulture, Georgia Station, The University of Georgia, 1109 Experiment Street, \\ Griffin, GA 30223-1797
}

\author{
Lynne Seymour \\ Department of Statistics, The University of Georgia, Athens, GA 30602-1952
}

\begin{abstract}
ADDitional INDEX wORDS. photosynthesis, dark respiration, carbon use efficiency, conversion efficiency, glucose requirement, maintenance coefficient, Catharanthus roseus
\end{abstract}

\begin{abstract}
Respiration is important in the overall carbon balance of plants, and can be separated into growth ( $\left.R_{\mathrm{g}}\right)$ and maintenance respiration $\left(R_{m}\right)$. Estimation of $R_{g}$ and $R_{m}$ throughout plant development is difficult with traditional approaches. Here, we describe a new method to determine ontogenic changes in $R_{g}$ and $R_{m}$. The $\mathrm{CO}_{2}$ exchange rate of groups of 28 'Cooler Peppermint' vinca plants [Catharanthus roseus (L.) G. Don.] was measured at 20 min intervals for 2 weeks. These data were used to calculate daily carbon gain (DCG, a measure of growth rate) and cumulative carbon gain (CCG, a measure of plant size). Growth and maintenance respiration were estimated based on the assumption that they are functions of DCG and CCG, respectively. Results suggested a linear relationship between DCG and $R_{\mathrm{g}}$. Initially, $R_{m}$ was three times larger than $R_{g}$, but they were similar at the end of the experiment. The decrease in the fraction of total available carbohydrates that was used for $R_{m}$ resulted in an increase in carbon use efficiency from 0.51 to 0.67 $\mathrm{mol} \cdot \mathrm{mol}^{-1}$ during the 2-week period. The glucose requirement of the plants was determined from $R_{\mathrm{g}}, \mathrm{DCG}$, and the carbon fraction of the plant material and estimated to be $1.39 \mathrm{~g} \cdot \mathrm{g}^{-1}$, while the maintenance coefficient was estimated to be 0.031

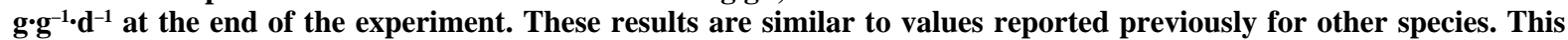
suggests that the use of semicontinuous $\mathrm{CO}_{2}$ exchange measurements for estimating $\mathrm{R}_{\mathrm{g}}$ and $\mathrm{R}_{\mathrm{m}}$ yields reasonable results.
\end{abstract}

Carbon accumulation is the primary process for plant biomass production, and depends both on photosynthesis and respiration. The relationship between photosynthesis and plant growth has been studied extensively, but the importance of respiration is commonly underestimated, even though respiration is very important in the overall carbon balance of plants (Jiao et al., 1996). The carbon use efficiency of plants (CUE, the amount of carbon incorporated into dry matter divided by the total amount of carbon fixed in the photosynthetic process) is normally only $50 \%$ to $70 \%$ (Amthor, 1989). This implies that the other $30 \%$ to $50 \%$ of the carbohydrates fixed in photosynthetic processes are respired.

Carbon fixation by plants can be measured as their $\mathrm{CO}_{2}$ exchange rate. These measurements yield net photosynthesis $\left(\mathrm{P}_{\mathrm{n}}\right)$ during the light period and dark respiration $\left(\mathrm{R}_{\mathrm{d}}\right)$ during the dark period. Gross photosynthesis $\left(\mathrm{P}_{\mathrm{g}}\right)$ is calculated as $\mathrm{P}_{\mathrm{n}}+\mathrm{R}_{\mathrm{d}}$, based on the common assumption that respiration is similar in the light and in the dark (e.g., Gifford, 1995; McCree, 1982; van Iersel and Bugbee, 2000). Dark respiration of plants can be divided into two different physiological processes: growth respiration $\left(\mathrm{R}_{\mathrm{g}}\right)$ and maintenance respiration $\left(\mathrm{R}_{\mathrm{m}}\right)$. Growth respiration is defined as the amount of carbohydrates respired in processes that result in a net gain in plant biomass. This includes the production of ATP and reductant for biosynthetic processes, transport processes, and nutrient uptake and reduction (Chiariello et al., 1989). Mainte-

Received for publication 17 Dec. 1999. Accepted for publication 19 June 2000. We thank Keven Calhoun and Larry Freeman for technical assistance and The University of Georgia Research Foundation for financial support. Mention of brand names is for information only and does not constitute an endorsement to the exclusion of other products that may also be suitable. The cost of publishing this paper was defrayed in part by the payment of page charges. Under postal regulations, this paper therefore must be hereby marked advertisement solely to indicate this fact.

${ }^{1}$ To whom reprint requests should be addressed; e-mail: mvanier@gaes.griffin.peachnet.edu. nance respiration is defined as the respiration needed to provide the energy for all plant processes that do not result in a net increase in plant dry matter, such as maintenance of ion gradients across membranes and the resynthesis of degraded organic compounds (Chiariello et al., 1989).

Growth respiration can be used to calculate the conversion efficiency $\left[\mathrm{Y}_{\mathrm{g}}\left(\mathrm{g} \cdot \mathrm{g}^{-1}\right)\right.$, the amount of plant dry matter $(\mathrm{g})$ produced from $1 \mathrm{~g}$ of glucose], while $\mathrm{R}_{\mathrm{m}}$ is used to determine the maintenance coefficient [the amount of glucose respired for maintenance per unit dry weight (DW) per $\left.\mathrm{d}, \mathrm{g} \cdot \mathrm{g}^{-1} \cdot \mathrm{d}^{-1}\right]$. Both the conversion efficiency and the maintenance coefficient are important parameters in crop growth models (Gifford et al., 1995; Heuvelink, 1995).

Growth respiration $\left(\mathrm{R}_{\mathrm{g}}\right)$ and $\mathrm{R}_{\mathrm{m}}$ are difficult to separate, because there is no clear distinction at the biochemical level and both processes result in a $\mathrm{CO}_{2}$ efflux from plants. Therefore, they cannot be measured separately and are estimated commonly using physiological models (McCree, 1982; Thornley, 1970; Thornley and Johnson, 1990). In these models, it is normally assumed that $\mathrm{R}_{\mathrm{g}}$ is proportional to the growth rate of the plants, while $R_{m}$ is proportional to the DW of the plant (Chiariello et al., 1989). This last assumption is especially questionable, since $R_{m}$ depends not only on the weight, but also on the chemical composition of the plant. Plants contain a significant amount of nonbiodegradable compounds (e.g., lignin), that do not require maintenance (McCree, 1982), while proteins require a relatively large amount of maintenance (Johnson, 1990; Thornley, 1977). The fractions of nonbiodegradable biomass and proteins may change during plant development, which would likely affect $R_{m}$ and the maintenance coefficient. In addition, many current approaches to estimating $R_{g}$ and $R_{m}$ rely on occasional, infrequent measurement of respiration. Because there are distinct daily fluctuations in the respiration rate of plants (Seymour, 1999; van Iersel and Bugbee, 2000), these measurements may not be an accurate estimate of the respiration rate throughout the day. 
Other approaches for estimating $\mathrm{R}_{\mathrm{g}}$ and $\mathrm{R}_{\mathrm{m}}$ are based on the chemical composition of the plant material (Penning de Vries et al., 1974) or the heat of combustion and organic nitrogen content of the plant tissue (Williams et al., 1987). These methods require destructive sampling, and are thus not well-suited to determining developmental changes in the conversion efficiency or maintenance coefficient.

There has been little improvement in techniques for studying $\mathrm{R}_{\mathrm{g}}$ and $\mathrm{R}_{\mathrm{m}}$ since the initial work by McCree (1974), Penning de Vries et al. (1974), and Thornley (1970). Studying changes in $R_{g}$ and $R_{m}$ throughout plant development has been difficult. Using a combination of semicontinuous, whole-plant $\mathrm{CO}_{2}$ exchange measurements and time series analysis (a new statistical approach to analyzing this type of data; Seymour, 1999), we describe a nondestructive approach for determining $\mathrm{R}_{\mathrm{g}}$ and $\mathrm{R}_{\mathrm{m}}$ throughout plant development. Our approach does not assume linear relationships between growth rate and $R_{g}$, or plant DW and $R_{m}$, making it easier to detect changes during plant development. This new approach is based on the premise that the $\mathrm{CO}_{2}$ exchange rate of plants can be used as a measure of the growth rate, while the total amount of carbon in the plant can be used as a measure of plant size. Indeed, it has been argued that expressing plant weight in terms of carbon equivalents is a convenient approach to whole-plant respiration and growth research (Thornley and Johnson, 1990).

\section{Materials and Methods}

Plant material. 'CoolerPeppermint' vinca seeds (Catharanthus roseus) were planted in a peat-based growing mix (Redi-Earth; The Scotts Co., Marysville, Ohio) and germinated in the dark at $20^{\circ} \mathrm{C}$. The seedlings were subsequently transferred to a double-layer polyethylene greenhouse and grown until the second pair of true leaves appeared. Temperature set points for the greenhouse were days/nights of $23 / 18^{\circ} \mathrm{C}$. The seedlings were then transplanted into cell packs ( $166 \mathrm{~mL} / \mathrm{cell}$ ) filled with diatomaceous earth (Isolite CG2; Sundine Enterprises, Arvada, Col.). During transplanting, most of the growing mix was removed from the root system by dipping the roots in water. Diatomaceous earth was used as a posttransplant growing medium in this experiment, because it is easy to remove from the root system and thus facilitates accurate plant DW measurements. Diatomaceous earth is a chemically inert growing substrate consisting mainly of $\mathrm{SiO}_{2}(78 \%), \mathrm{Al}_{2} \mathrm{O}_{3}(12 \%)$, and $\mathrm{Fe}_{2} \mathrm{O}_{3}$ $(5 \%)$, with a low cation exchange capacity $\left(<0.02 \mathrm{meq} \cdot \mathrm{g}^{-1}\right)$.

Eight groups of 28 seedlings were placed in watertight trays and transferred to transparent acrylic chambers $\left(3.2 \times 5 \times 6 \mathrm{dm}^{3}\right)$, which were placed inside two larger growth chambers (model E-15; Conviron, Asheville, N.C.). The plants were watered as needed with a complete $20 \mathrm{~N}-4.4 \mathrm{P}-16.6 \mathrm{~K}$ water-soluble fertilizer (20-10-20 Peat-Lite Special; The Scotts Co.), containing N at $100 \mathrm{mg} \cdot \mathrm{L}^{-1}$. Environmental conditions inside the chamber were 14 $\mathrm{h}$ days $/ 10 \mathrm{~h}$ nights of $22 / 18^{\circ} \mathrm{C}$, and a photosynthetic photon flux of $425 \mu \mathrm{mol} \cdot \mathrm{m}^{-2} \cdot \mathrm{s}^{-1}$ at the canopy level. This resulted in a total daily photon flux of $21.4 \mathrm{~mol} \cdot \mathrm{m}^{-2}$. Relative humidity inside the acrylic chambers was $\approx 75 \%$ during the light period and $100 \%$ at night.

Carbon dioxide exchange MEASUREMENTS. Whole-plant carbon exchange rate (CER) of each group of 28 plants was measured with an open $\mathrm{CO}_{2}$ exchange system (van Iersel and Bugbee, 2000). Ambient air was blown into the acrylic chamber and air flow was measured with mass flow meters (GFM37-32; Aalborg Instruments and Controls, Monsey, N.Y.). The difference in the $\mathrm{CO}_{2}$ concentration of the air entering and exiting the chamber was measured with an infrared gas analyzer (LI-6251; LI-COR, Lincoln, Nebr.). Whole chamber CER $\left(\mu \mathrm{mol} \cdot \mathrm{s}^{-1}\right)$ was calculated as the product of mass flow $\left(\mathrm{mol} \cdot \mathrm{s}^{-1}\right)$ and the difference in $\mathrm{CO}_{2}$ concentration $\left(\mu \mathrm{mol} \cdot \mathrm{mol}^{-1}\right)$. Gas exchange data of each group of plants were collected at $20 \mathrm{~min}$ intervals until $26 \mathrm{~d}$ after transplanting. Both $\mathrm{P}_{\mathrm{n}}$ and $\mathrm{R}_{\mathrm{d}}$ data are reported as positive quantities and all data represent the CER of groups of 28 plants. To give the plants ample time to get established and adjust to the conditions in the gas exchange system, the data from the first $12 \mathrm{~d}$ of the experiment were not used for analysis.

Since whole plants, including the containers, were enclosed in the gas exchange chamber, CER measurements included root-zone respiration. Root-zone respiration consists of respiration by the roots and by microorganisms in the growing medium. Since root respiration is part of the whole plant metabolism, this should be included in whole plant CER measurements. Microbial respiration resulting from the breakdown of organic products leaking from plant roots also should be included in whole plant net CER measurements, since the carbon in these compounds was originally fixed in the photosynthetic process but is no longer available for plant growth after it leaks from the roots (van Iersel and Bugbee, 2000).

Data ANALYSIS. Growth rates in the eight gas exchange chambers differed because of experimental treatments (van Iersel, 1999). To assure that comparisons among plants from different chambers were meaningful, we selected data from three chambers with similar growth rates for determination of $R_{g}$ and $R_{m}$.

The interpretation of continuous CER data is difficult with standard statistical techniques, because the data are both serially and periodically correlated. Serial correlation means that an observation at any given time are correlated with the prior observations, while periodic correlation means that the data at any given time are correlated with data from the same time during prior days (i.e., there are regular daily patterns in the CER of plants). This type of data cannot be analyzed adequately with standard regression techniques, but periodic time series analysis has been developed to analyze this type of periodically correlated data (Seymour, 1999). Time series techniques were used to fit regression curves to long-term $P_{n}$ and $R_{d}$ data, resulting in estimates $\mathrm{P}_{\mathrm{n}}{ }^{*}$ and $\mathrm{R}_{\mathrm{d}}{ }^{*}\left(\mathrm{~mol} \cdot \mathrm{s}^{-1}\right)$, respectively. These estimates were used to calculate the gross photosynthesis, growth rate or daily carbon gain, cumulative carbon gain, and carbon use efficiency:

$\mathrm{P}_{\mathrm{g}}^{*}=\mathrm{P}_{\mathrm{n}}^{*}+\mathrm{R}_{\mathrm{d}}^{*}$

$\mathrm{DCG}=\left(\mathrm{t}_{\text {light }} \times \mathrm{P}_{\mathrm{n}}^{*}\right)-\left(\mathrm{t}_{\mathrm{dark}} \times \mathrm{R}_{\mathrm{d}}^{*}\right)$

$\mathrm{CCG}=\int \mathrm{DCG} \mathrm{dt}$

$\mathrm{CUE}=\mathrm{DCG} /\left(\mathrm{t}_{\text {light }} \times \mathrm{P}_{\mathrm{g}}^{*}\right)$

where $\mathrm{P}_{\mathrm{g}}{ }^{*}=$ estimated gross photosynthesis $\left(\mu \mathrm{mol} \cdot \mathrm{s}^{-1}\right) ; \mathrm{P}_{\mathrm{n}}^{*}=$ estimated net photosynthesis $\left(\mu \mathrm{mol} \cdot \mathrm{s}^{-1}\right) ; \mathrm{R}_{\mathrm{d}}{ }^{*}=$ estimated dark respiration $\left(\mu \mathrm{mol} \cdot \mathrm{s}^{-1}\right) ; \mathrm{t}_{\text {light }}=$ duration of the light period $\left(\mathrm{s} \cdot \mathrm{d}^{-1}\right)$; $\mathrm{t}_{\text {dark }}=$ duration of the dark period $\left(\mathrm{s} \cdot \mathrm{d}^{-1}\right) ; \mathrm{DCG}=$ daily carbon gain $\left(\mathrm{mol} \cdot \mathrm{d}^{-1}\right) ; \mathrm{CCG}=$ cumulative carbon gain $(\mathrm{mol} \mathrm{C})$; and $\mathrm{CUE}=$ carbon use efficiency $\left(\mathrm{mol} \cdot \mathrm{mol}^{-1}\right.$, calculated according to van Iersel and Bugbee, 2000).

Note that $\mathrm{CCG}$ is a measure of carbon or biomass accumulation since the start of the experiment; a CCG of zero does not indicate that the plant DW was zero, but rather that there was no increase in the amount of $\mathrm{C}$ in the plant since the start of the CER measurements.

Since growth respiration $\left(\mathrm{R}_{\mathrm{g}}\right)$ is a function of the growth rate, and maintenance respiration $\left(\mathrm{R}_{\mathrm{m}}\right)$ a function of plant size, dark respiration $\left(\mathrm{R}_{\mathrm{d}}\right)$ can be expressed as a function $\left(f_{l}\right)$ of growth rate plus a function $\left(f_{2}\right)$ of plant size:

$\mathrm{R}_{\mathrm{d}}=\mathbf{R}_{\mathrm{g}}+\mathbf{R}_{\mathrm{m}}=f_{1}($ growth rate $)+f_{2}$ (plant size $) \quad[5]$

These functions are not necessarily linear, and their shape can be determined from the data. In this case, we found that a modified Richards function described the data accurately $\left(R^{2}>0.99\right)$ : 


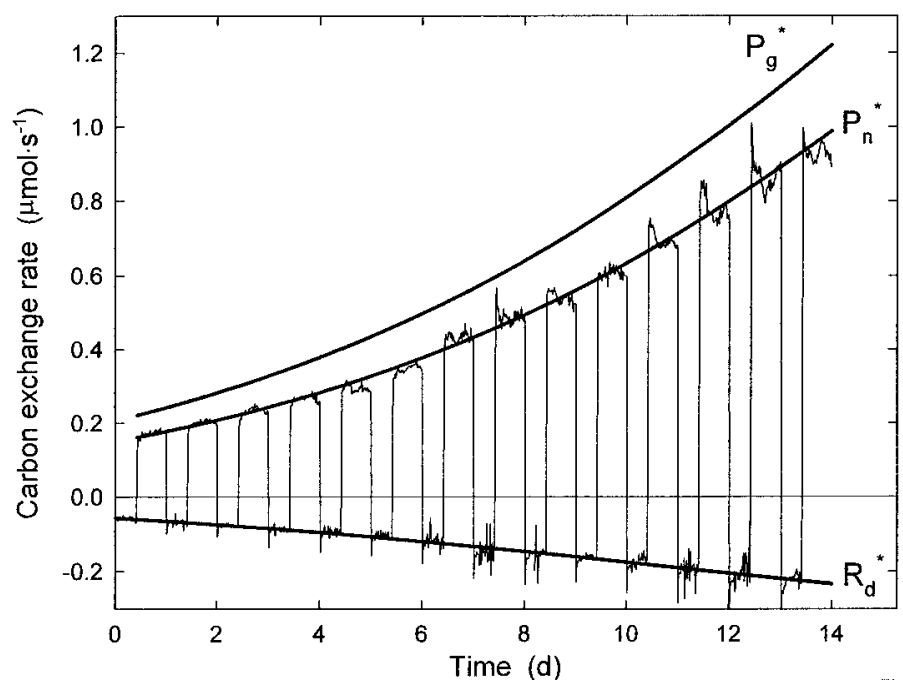

Fig. 1. Carbon exchange rate of a group of 28 vinca plants during a 14-d period. The bold lines indicate the estimated net photosynthesis $\left(\mathrm{P}_{\mathrm{n}}{ }^{*}\right)$, dark respiration $\left(\mathrm{R}_{\mathrm{d}}{ }^{*}\right)$, and gross photosynthesis $\left(\mathrm{P}_{\mathrm{g}}{ }^{*}\right)$ using time series analysis. Note that $\mathrm{R}_{\mathrm{d}}{ }^{*}$ has a negative value in this figure, because it relates to the $\mathrm{CO}_{2}$ exchange rate of the plants. In the rest of this paper, $\mathrm{R}_{\mathrm{d}}{ }^{*}$ refers to the $\mathrm{CO}_{2}$ efflux from the plants and has a positive value.

$\mathrm{R}_{\mathrm{d}}^{*}=\mathrm{R}_{\mathrm{m}}+\mathrm{R}_{\mathrm{g}}=\mathrm{x}_{0}+\mathrm{x}_{1} \times\left(1+\mathrm{e}^{\left(\mathrm{X}^{1}-\mathrm{X}^{2} \times \mathrm{CCG}\right)}\right)^{\mathrm{x}^{3}}+\mathrm{y} \times \mathrm{DCG}$

where $\mathrm{x}_{0}, \mathrm{x}_{1}, \mathrm{x}_{2}, \mathrm{x}_{3}$, and $\mathrm{y}$ are regression coefficients; $\mathrm{R}_{\mathrm{m}}=$ maintenance respiration $\left(\mu \mathrm{mol} \cdot \mathrm{s}^{-1}\right) ; \mathrm{R}_{\mathrm{g}}=\operatorname{growth}$ respiration $\left(\mu \mathrm{mol} \cdot \mathrm{s}^{-1}\right) ; \mathrm{R}_{\mathrm{d}}{ }^{*}$ $=$ estimated dark respiration $\left(\mu \mathrm{mol} \cdot \mathrm{s}^{-1}\right) ; \mathrm{DCG}=$ daily carbon gain $\left(\mathrm{mol} \cdot \mathrm{d}^{-1}\right)$; and $\mathrm{CCG}=$ cumulative carbon gain $(\mathrm{mol} \mathrm{C})$. This modified Richards function is flexible and was fitted with the nonlinear regression procedure (PROC NLIN) of SAS (SAS Inst., Inc., Cary, N.C.).

When the growth rate (or DCG) is zero, growth respiration $\left(\mathrm{R}_{\mathrm{g}}\right)$ is by definition zero, thus:

$\mathrm{R}_{\mathrm{m}}=\mathrm{x}_{0}+\mathrm{x}_{1} \times\left(1+\mathrm{e}^{\left(\mathrm{X}^{1}-\mathrm{X}^{2} \times \mathrm{CCG}\right)}\right) \mathrm{x}^{3}$

$\mathrm{R}_{\mathrm{g}}=\mathrm{y} \times \mathrm{DCG}$

These two functions were chosen based on a preliminary analysis of data from eight gas-exchange chambers (van Iersel, 2000). That analysis indicated there was a linear relationship between $R_{g}$ and DCG, but not between $R_{m}$ and CCG.

Growth respiration can be used to calculate the conversion efficiency $\left(Y_{g}\right)$ and the glucose requirement $\left[1 / Y_{g}\left(g \cdot g^{-1}\right)\right.$, the amount of glucose needed to produce $1 \mathrm{~g}$ of plant material] of the plants. Because the conversion efficiency and the glucose requirement are used as indicators of the biochemical efficiency of the conversion of glucose into new plant material, the glucose lost in $\mathrm{R}_{\mathrm{m}}$ is normally not included in these estimates. Thus, the glucose requirement (1/ $Y_{g}$ ) can be calculated as the sum of the amount of glucose used in $R_{g}$ to produce new plant material and the amount of glucose needed to provide the carbon for the new plant material.

$\begin{array}{rll}1 / \mathrm{Y}_{\mathrm{g}} & =\left[\left(30 \times \mathrm{F}_{\mathrm{C}} \times \mathrm{R}_{\mathrm{g}}\right) /(\mathrm{DCG} \times 12)\right]+\left(30 \times \mathrm{F}_{\mathrm{C}} / 12\right) & {[9 \mathrm{a}]} \\ & =2.5 \times \mathrm{F}_{\mathrm{C}} \times\left[\left(\mathrm{R}_{\mathrm{g}} / \mathrm{DCG}\right)+1\right] & {[9 \mathrm{~b}]}\end{array}$

where $F_{C}=$ carbon fraction of the plants $\left(g \cdot g^{-1}\right) ; R_{g}=$ growth respiration (for simplicity now expressed in units of $\mathrm{mol} \cdot \mathrm{d}^{-1}$, instead of $\left.\mathrm{mol} \cdot \mathrm{s}^{-1}\right)$; DCG = daily carbon gain $\left(\mathrm{mol} \cdot \mathrm{d}^{-1}\right) ; 30\left(\mathrm{~g} \cdot \mathrm{mol}^{-1}\right)$ converts moles of $\mathrm{CO}_{2}$ to grams of glucose; and $12\left(\mathrm{~g} \cdot \mathrm{mol}^{-1}\right)$ converts moles of $\mathrm{C}$ to grams of $\mathrm{C}$. The first part of Eq. [9a] determines how much glucose is respired $\left[\left(30 \times \mathrm{F}_{\mathrm{C}} \times \mathrm{R}_{\mathrm{g}}\right) /(\mathrm{DCG} \times\right.$ 12)], while the second part of the equation calculates the amount of glucose needed to provide the carbon for the new plant material (30 $\left.\times \mathrm{F}_{\mathrm{C}} / 12\right)$.
In this experiment, $\mathrm{F}_{\mathrm{C}}$ of the plants was only determined at the end of the experiment, since destructive sampling would have interfered with the CER measurements. Therefore, it is assumed that $\mathrm{F}_{\mathrm{C}}$ was constant. This same assumption has been made previously in similar research (e.g., Monje and Bugbee, 1998).

\section{Results and Discussion}

Both $P_{n}$ and $R_{d}$ of the plants increased during the 14-d period. Example data from one of the groups of plants are illustrated in Fig. 1. The increase in $P_{n}$ was likely the result of increased light interception by the expanding canopy, while $R_{d}$ increased because of increasing $R_{m}$ and $R_{g}$ as the plants became larger and the growth rate increased. The plants never became large enough to intercept all the radiation, at which point $P_{n}$ would be expected to reach a maximum.

Carbon use efficiency of the plants also increased from 0.51 to $0.67 \mathrm{~mol} \cdot \mathrm{mol}^{-1}$ over time and with increasing plant size (Fig. 2A and $\mathrm{B}$ ), which is within the range of normal values for CUE (Amthor, 1989). This increase in CUE is consistent with the finding of Winzeler et al. (1976) that the ratio of respiration to photosynthesis of young uniculm barley (Hordeum vulgare L.) plants decreases during the first few weeks of plant development. An increase in CUE indicates that a smaller fraction of the carbohydrates fixed in the photosynthetic process was lost by respiration as the plants became larger. This more efficient use of carbohydrates suggests that there was a fundamental change in the fraction of carbohydrates allocated to respiratory processes $\left(\mathrm{R}_{\mathrm{m}}\right.$ and/or $\left.\mathrm{R}_{\mathrm{g}}\right)$ in the plants.

The estimates for $R_{m}$ and $R_{g}$ are illustrated in Fig. 3A, together with $R_{d}{ }^{*}$. Both $R_{m}$ and $R_{g}$ increased throughout the experiment. Initially, $\mathrm{R}_{\mathrm{m}}$ was much larger than $\mathrm{R}_{\mathrm{g}}$ and accounted for $76 \%$ of $\mathrm{R}_{\mathrm{d}}{ }^{*}$ (Fig. 3B). Growth respiration increased more rapidly than $\mathrm{R}_{\mathrm{m}}$ and at the end of the $14-d$ period, $R_{m}$ accounted for $55 \%$ and $R_{g}$ for $45 \%$ of $\mathrm{R}_{\mathrm{d}}$.

The regression results indicate that the relationship between DCG and $\mathrm{R}_{\mathrm{g}}$ was linear (Eq. [8], Fig. 4). The slope of the regression line of $\mathrm{R}_{\mathrm{g}}$ versus DCG was $2.69 \pm 0.93\left(\mu \mathrm{mol} \cdot \mathrm{s}^{-1}\right) /\left(\mathrm{mol} \cdot \mathrm{d}^{-1}\right)$, or 0.232 $\pm 0.080 \mathrm{~mol} \cdot \mathrm{mol}^{-1}$ (mean $\left.\pm \mathrm{SE}\right)$. This indicates that $\mathrm{R}_{\mathrm{g}}$ accounted for $0.232 \mathrm{~mol}$ of $\mathrm{CO}_{2} / \mathrm{mol}$ of $\mathrm{C}$ that was incorporated into the plants. This value can be used to calculate a theoretical maximum value for the CUE of these plants, which is achieved when $R_{m}$ is a negligible

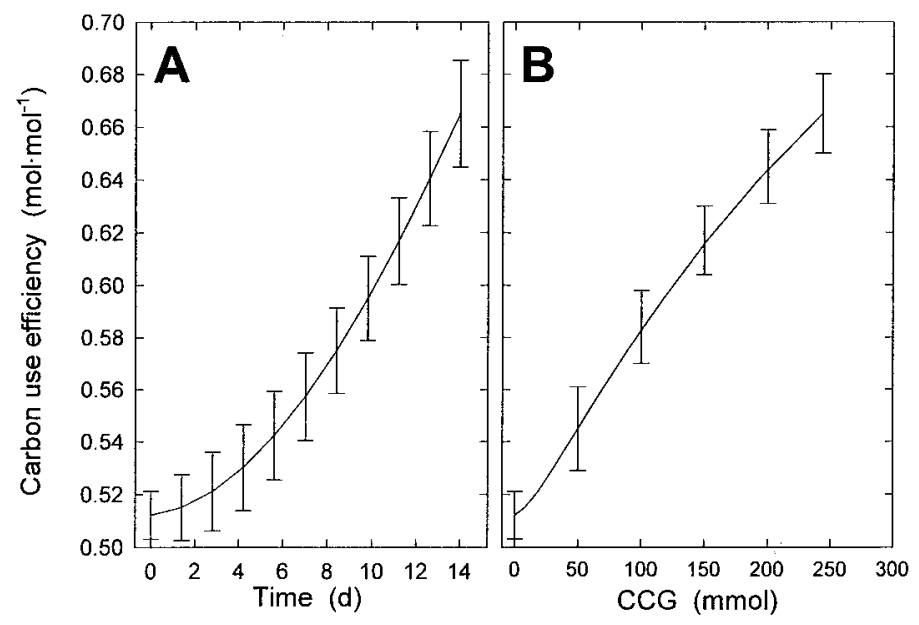

Fig. 2. Carbon use efficiency (mean $\pm \mathrm{SE}$ ) of three groups of 28 vinca plants as a function of $(\mathbf{A})$ time and $(\mathbf{B})$ cumulative carbon gain (CCG), a measure of plant size. 

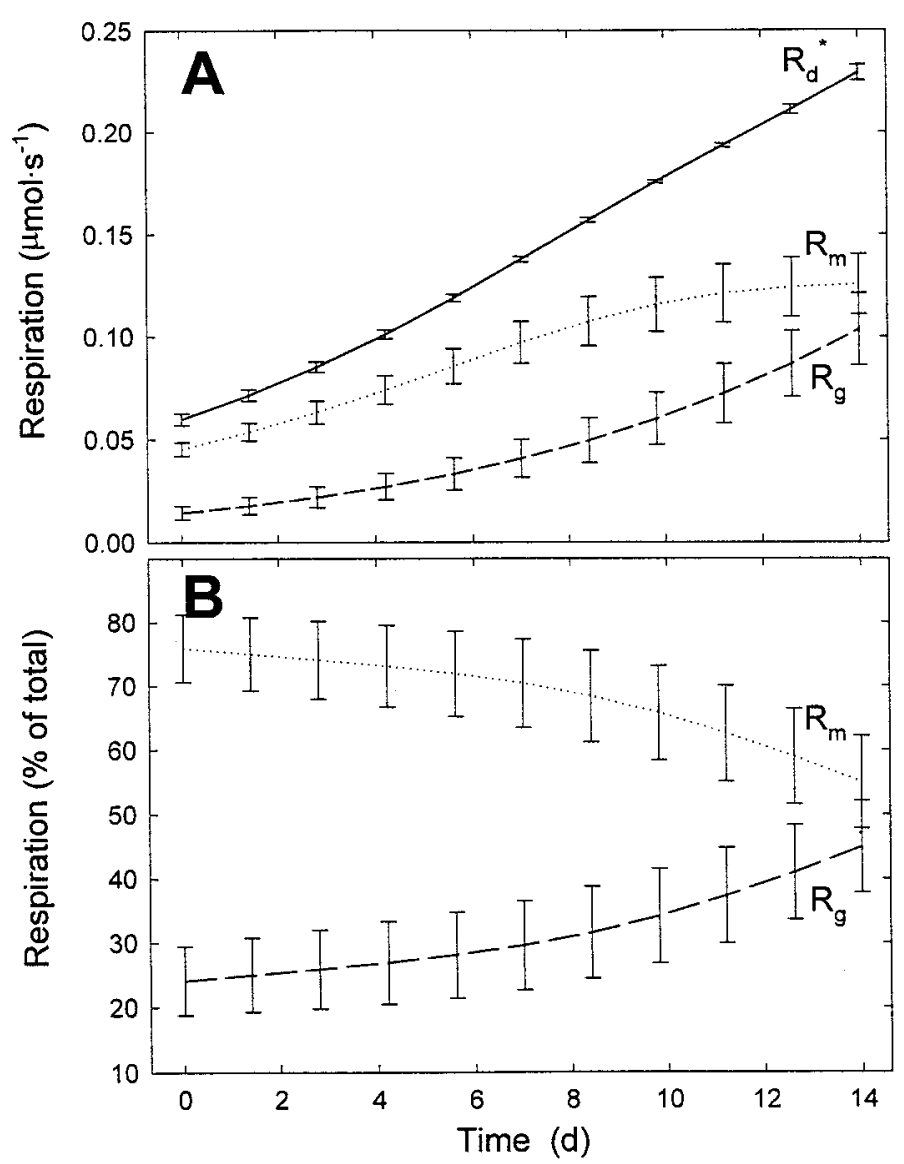

Fig. 3. Estimated dark $\left(\mathrm{R}_{\mathrm{d}}{ }^{*}\right)$, growth $\left(\mathrm{R}_{\mathrm{g}}\right)$, and maintenance respiration $\left(\mathrm{R}_{\mathrm{m}}\right)$ of three groups of 28 vinca plants during a 14-d period (mean $\pm \mathrm{SE}$ ). Estimates of $\mathrm{R}_{\mathrm{g}}$ and $\mathrm{R}_{\mathrm{m}}$ were based on the assumption that $\mathrm{R}_{\mathrm{g}}$ is a function of the growth rate and $R_{m}$ is a function of the plant size. The respiration data are shown both as (A) their actual rate and as $(\mathbf{B})$ a percentage of total dark respiration.

part of total respiration (i.e., all respiration is $\mathrm{R}_{\mathrm{g}}$ ). To add $1 \mathrm{~mol}$ of $\mathrm{C}$ to the plant, a total of $1.232 \mathrm{~mol} \mathrm{C}$ is needed $(1 \mathrm{~mol}$ that is incorporated into the plant plus $0.232 \mathrm{~mol}$ that is respired), so the maximum CUE that these plants could reach was $0.812 \mathrm{~mol} \cdot \mathrm{mol}^{-1}$ (1/1.232). Carbon use efficiency was lower than this theoretical maximum, because a significant fraction of the available carbohydrates was used for $\mathrm{R}_{\mathrm{m}}$ (Fig. 3).

Since both the growth rate and $\mathrm{R}_{\mathrm{g}}$ of the plants are known, the conversion efficiency $\left(\mathrm{Y}_{\mathrm{g}}\right)$ of the plants can be calculated using Eq. [9b]. The carbon fraction of the plants at the end of the experiment was 0.45 and was assumed to have been constant throughout the 14$\mathrm{d}$ growing period. Since $\mathrm{R}_{\mathrm{g}} / \mathrm{DCG}$ also was constant throughout the experiment (Fig. 4), the glucose requirement $\left(1 / \mathrm{Y}_{\mathrm{g}}\right)$ of the plants was constant and estimated to be $1.39 \pm 0.05 \mathrm{~g}$ of glucose per $\mathrm{g}$ of newly produced biomass (mean $\pm \mathrm{SE}$ ). This estimate is very close to the commonly used values of 1.39 and $1.45 \mathrm{~g} \cdot \mathrm{g}^{-1}$ for leaves and stems of nonleguminous species, respectively (Penning de Vries et al., 1989). It is also close to the $1.34,1.54$, and $1.46 \mathrm{~g} \cdot \mathrm{g}^{-1}$ reported for whole soybean [Glycine $\max (\mathrm{L}$.) Merr.] and sorghum [Sorghum bicolor (L.) Moench] plants (Amthor et al., 1994), and leaves of yellow-poplar (Liriodendron tulipifera L.) (Wullschleger et al., 1997), respectively. A glucose requirement of $1.39 \mathrm{~g} \cdot \mathrm{g}^{-1}$ yields a conversion efficiency of $0.72 \mathrm{~g} \cdot \mathrm{g}^{-1}$, which is well within the normal range of 0.6 to $0.8 \mathrm{~g} \cdot \mathrm{g}^{-1}$ (McCree, 1982).

The maintenance coefficient was also close to previously reported values. At the end of the experiment, the DW of the plants was
$10.6 \pm 0.7 \mathrm{~g}$, while the final $\mathrm{R}_{\mathrm{m}}$ was $0.125 \pm 0.015 \mu \mathrm{mol} \cdot \mathrm{s}^{-1}$. Thus, maintenance respiration was $0.012 \pm 0.002 \mu \mathrm{mol} \cdot \mathrm{g}^{-1} \cdot \mathrm{s}^{-1}$, resulting in a maintenance coefficient of $0.031 \pm 0.004 \mathrm{~g} \cdot \mathrm{g}^{-1} \cdot \mathrm{d}^{-1}$. Most previously reported values range from 0.003 to $0.050 \mathrm{~g} \cdot \mathrm{g}^{-1} \cdot \mathrm{d}^{-1}$ (Hesketh et al., 1980). The maintenance coefficient of plants is much more variable than the conversion efficiency, because it depends on the age of the plant and the environmental conditions, especially temperature (Mariko and Koizumi, 1993; Walker and Thornley, 1977).

The overall distribution of the available carbohydrates among growth, $\mathrm{R}_{\mathrm{g}}$, and $\mathrm{R}_{\mathrm{m}}$ during this 14-d experiment is shown in Fig. 5. Based on the results of this analysis, it is evident that CUE increased throughout the 14-d period, because a smaller fraction of the total available carbohydrates was used for $\mathrm{R}_{\mathrm{m}}$ as the plants became larger. Thus, a larger fraction of the carbohydrates was available for growth and $\mathrm{R}_{\mathrm{g}}$, increasing CUE.

The comparison of our estimates of $\mathrm{R}_{\mathrm{g}}$ and $\mathrm{R}_{\mathrm{m}}$ with previously reported values suggests that our approach results in reasonable estimates. However, an important difference between our approach and previous research is that we did not have to assume a linear relationship between growth and $R_{g}$ or between plant size and $R_{m}$. Indeed, we found that the relationship between plant size and $R_{m}$ was not linear (Eq. [7]). This is consistent with previous work: based on $\mathrm{CO}_{2}$ exchange measurements throughout the life cycle of barley, Winzeler et al. (1976) found that a linear relationship between $R_{m}$ and plant DW did not describe the experimental data adequately, especially early in the life cycle. Similarly, Hughes (1973) found that a linear model resulted in a negative $R_{m}$ during the early development of chrysanthemum (Dendranthema $\times$ grandiflorum Kitam.). The findings of Hughes (1973) and Winzeler et al. (1976) indicate that modeling $\mathrm{R}_{\mathrm{g}}$ and $\mathrm{R}_{\mathrm{m}}$ as linear functions of growth rate and DW respectively, is an oversimplification of the whole-plant carbon balance. It seems likely that $R_{g}, R_{m}$, the conversion efficiency, and the maintenance coefficient depend on tissue, organ, and plant age (Gary et al., 1998b; Thornley and Johnson, 1990), as well as many physiological and environmental factors (Amthor, 1989). For example, a high mineral content of plant material can result in an increase in the conversion efficiency, because of the relative dilution of the organic matter in the plant (Gary et al., 1998a). The main reason that the assumption of linear relationships between growth rate and $R_{g}$ and between plant weight and $R_{m}$ is commonly made appears to be its simplicity. It allows for estimating

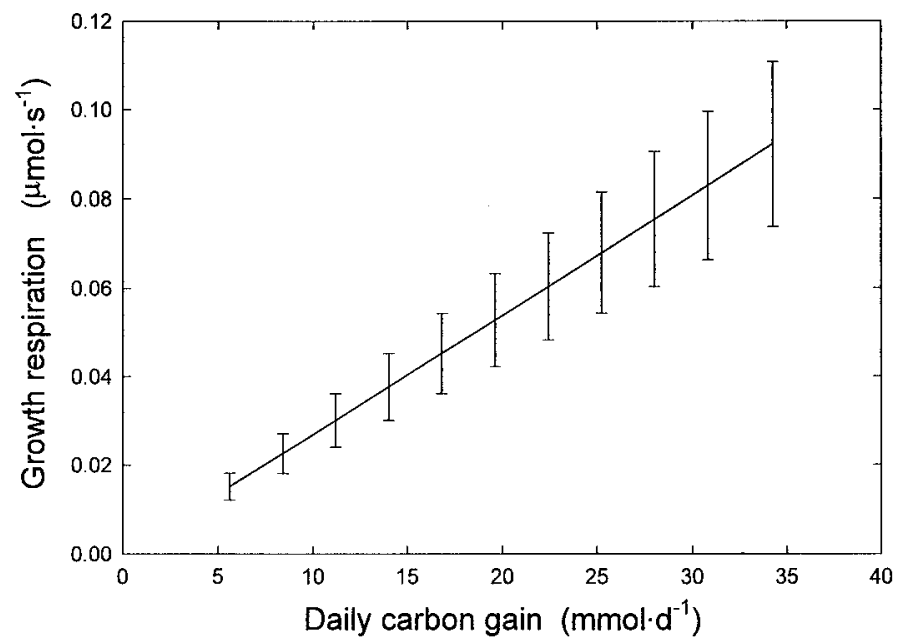

Fig. 4. Estimated growth respiration as a function of daily carbon gain (a measure of growth rate) of three groups of 28 vinca plants during a 14-d period (mean $\pm \mathrm{sE}$ ). 


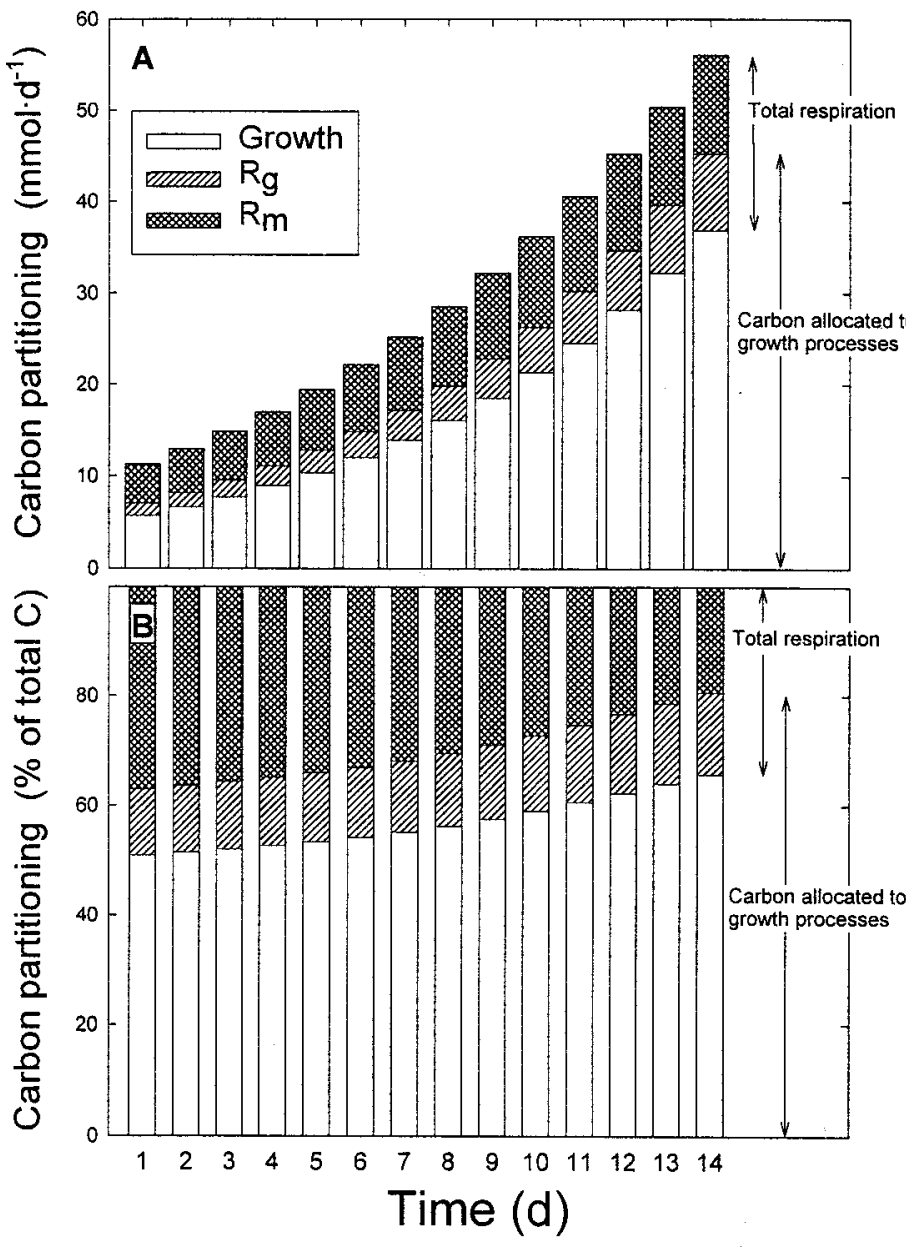

Fig. 5. Distribution of the total available carbohydrates among growth, growth respiration $\left(\mathrm{R}_{\mathrm{g}}\right)$, and maintenance respiration $\left(\mathrm{R}_{\mathrm{m}}\right)$ during a 2-week period, expressed as $(\mathbf{A})$ their actual rate and as $(\mathbf{B})$ a percentage of the total amount of available carbohydrates. Note that the fraction of carbohydrates allocated to $R_{m}$ decreases, even though $\mathrm{R}_{\mathrm{m}}$ increases with increasing plant age.

$\mathrm{R}_{\mathrm{g}}$ and $\mathrm{R}_{\mathrm{m}}$ from $\mathrm{CO}_{2}$ exchange measurements of plants with different growth rates (Chiariello et al., 1989).

Using semicontinuous CER measurements, we have developed a technique to estimate $\mathrm{R}_{\mathrm{g}}$ and $\mathrm{R}_{\mathrm{m}}$ that does not depend on the assumption of linear relationships between growth rate and $R_{g}$ or between plant weight and $\mathrm{R}_{\mathrm{m}}$. This makes it feasible to determine changes in $\mathrm{R}_{\mathrm{g}}$ and $\mathrm{R}_{\mathrm{m}}$ during plant development. Comparisons of our estimates of the conversion efficiency and maintenance coefficient indicate that this approach results in realistic estimates. This approach can be used to quantify the effects of cultural and environmental factors on $\mathrm{R}_{\mathrm{g}}$ and $\mathrm{R}_{\mathrm{m}}$.

\section{Literature Cited}

Amthor, J.S. 1989. Respiration and crop productivity. Springer-Verlag, N.Y.

Amthor, J.S., R.J. Mitchell, G.B. Runion, H.H. Rogers, S.A. Prior, and C.W. Wood. 1994. Energy content, construction cost and phytomass accumulation of Glycine max (L.) Merr. and Sorghum bicolor (L.) Moench grown in elevated $\mathrm{CO}_{2}$ in the field. New Phytol. 128:443-450. Chiariello, N.R., H.A. Mooney, and K. Williams. 1989. Growth, carbon allocation and cost of plant tissues, p. 327-365. In: R.W. Pearcy, J. Ehleringer, H.A. Mooney, and P.W. Rundel (eds.). Plant physiological ecology: Field methods and instrumentation. Chapman and Hall, N.Y.

Gary, C., N. Bertin, J.S. Frossard, and J. Le Bot. 1998a. High mineral content explains the low construction cost of leaves, stems and fruits of tomato plants. J. Expt. Bot. 49:49-57.

Gary, C., J. Le Bot, J.S. Frossard, and J.L. Andriolo. 1998b. Ontogenic changes in the construction cost of leaves, stems, fruits, and roots of tomato plants. J. Expt. Bot. 49:59-68.

Gifford, R.M. 1995. Whole plant respiration and photosynthesis of wheat under increased $\mathrm{CO}_{2}$ concentration and temperature: Long-term vs. short-term distinctions for modelling. Global Change Biol. 1:385-396.

Hesketh, J.D., R.S. Alberte, and J.W. Jones. 1980. Predicting dark respiration in the soil-plant system, p. 69-84. In: J.D. Hesketh and J.W. Jones (eds.). Predicting photosynthesis for ecosystem models. vol. II. CRC Press, Boca Raton, Fla.

Heuvelink, E. 1995. Dry matter production in a tomato crop: Measurements and simulation. Ann. Bot. 75:369-379.

Hughes, A.P. 1973. A comparison of the effects of light intensity and duration on Chrysanthemum morifolium cv. Bright. II. Ontogenetic changes in respiration. Ann. Bot. 37:275-280.

Jiao, J., E.D. Leonardos, and B. Grodzinski. 1996. Approaches to measuring plant bioproductivity and growth, p. 699-716. In: M. Pessarakli (ed.). Handbook of photosynthesis. Marcel Dekker, N.Y.

Johnson, I.R. 1990. Plant respiration in relation to growth, maintenance, ion uptake and nitrogen assimilation. Plant Cell Environ. 13:319-328.

Mariko, S. and H. Koizumi. 1993. Respiration for maintenance and growth in Reynoutria japonica ecotypes from different altitudes on MtFuji. Ecol. Res. 8:241-246.

McCree, K.J. 1974. Equations for the rate of dark respiration of white clover and grain sorghum, as functions of dry weight, photosynthetic rate and temperature. Crop Sci. 14:509-514.

McCree, K.J. 1982. Maintenance requirements of white clover at high and low growth rates. Crop Sci. 22:345-351.

Monje, O. and B. Bugbee. 1998. Adaptation to high $\mathrm{CO}_{2}$ concentration in an optimal environment: Radiation capture, canopy quantum yield and carbon use efficiency. Plant, Cell Environ. 21:315-324.

Penning de Vries, F.W.T., A.H.M. Brunsting, and H.H. van Laar. 1974. Products, requirements, and efficiency of biosynthesis: A quantitative approach. J. Theor. Biol. 45:339-377.

Penning de Vries, F.W.T., D.M. Jansen, H.F.M. Ten Berge, and A. Bakema. 1989. Simulation of ecophysiological processes of growth in several annual crops. Ctr. Agr. Publ. Documentation, Wageningen, The Netherlands.

Seymour, L. 1999. Regression with periodically correlated errors: A new model for plant growth. Tech. Rpt. 1999-12. Dept. Stat., Stanford Univ., Stanford, Calif.

Thornley, J.H.M. 1970. Respiration, growth and maintenance in plants. Nature 277:304-305.

Thornley, J.H.M. 1977. Growth, maintenance and respiration: A reinterpretation. Ann. Bot. 41:1191-1203.

Thornley, J.H.M. and I.R. Johnson. 1990. Plant and crop modelling: A mathematical approach to plant and crop physiology. Clarendon Press, Oxford, U.K.

van Iersel, M.W. 1999. Auxin applications affect post-transplant $\mathrm{CO}_{2}$ exchange rate and growth of vinca seedlings. J. Amer. Soc. Hort. Sci. 124:234-238.

van Iersel, M.W.2000. Growth and maintenance respiration of Catharanthus roseus L. estimated from $\mathrm{CO}_{2}$ exchange. Acta Hort. 519:133-140.

van Iersel, M.W. and B. Bugbee. 2000. A multiple chamber, semicontinuous, crop carbon dioxide exchange system: Design, calibration, and data interpretation. J. Amer. Soc. Hort. Sci. 125:86-92.

Walker, A.J. and J.H.M. Thornley. 1977. The tomato fruit: Import, growth, respiration, and carbon metabolism at different fruit sizes and temperatures. Ann. Bot. 41:977-985.

Williams, K., F. Percival, J. Merino, and H.A. Mooney. 1987. Estimation of tissue construction cost from heat of combustion and organic nitrogen content. Plant, Cell Environ. 10:725-734.

Winzeler, H., L.A. Hunt, and J.D. Mahon. 1976. Ontogenetic changes in respiration and photosynthesis in a uniculm barley. Crop Sci. 16:786790.

Wullschleger, S.D., R.J. Norby, J.C. Love, and C. Ruck. 1997. Energetic costs of tissue construction in yellow-poplar and white oak trees exposed to long-term $\mathrm{CO}_{2}$ enrichment. Ann. Bot. 80:289-297. 